\title{
Projecting climate change, drought conditions and crop productivity in Turkey
}

\author{
Burak Sen ${ }^{1}$, Sevilay Topcu ${ }^{2, *}$, Murat Türkeş ${ }^{3}$, Baha Sen ${ }^{4}$, Jeoren F. Warner ${ }^{5}$ \\ ${ }^{1}$ Turkish State Meteorological Service, Department of Weather Forecasting, Numerical Weather Prediction Division, \\ 06120 Kalaba-Ankara, Turkey \\ ${ }^{2}$ Department of Agricultural Structures and Irrigation, Faculty of Agriculture, Cukurova University, 01330 Adana, Turkey \\ ${ }^{3}$ Department of Geography, Faculty of Sciences and Arts, Canakkale Onsekiz Mart University, Terzioglu Campus, \\ 17020 Canakkale, Turkey \\ ${ }^{4}$ Department of Computer Engineering, Faculty of Engineering, Karabuk University, 78050 Karabuk, Turkey \\ ${ }^{5}$ Disaster Studies, Social Sciences Group, Wageningen University, Wageningen, The Netherlands
}

\begin{abstract}
This paper focuses on the evaluation of regional climate model simulation for Turkey for the 21st century. A regional climate model, ICTP-RegCM3, with $20 \mathrm{~km}$ horizontal resolution, is used to downscale the reference and future climate scenario (IPCC-A2) simulations. Characteristics of droughts as well as the crop growth and yields of first- and second-crop corn are then calculated and simulated based on the data produced. The model projects an increase in air temperature of 5 to $7^{\circ} \mathrm{C}$ during the summer season over the west and an increase of $3.5^{\circ} \mathrm{C}$ for the winter season for the eastern part of the country. Precipitation is predicted to be $40 \%$ less in the southwest, although it may increase by $25 \%$ in the eastern part of the Black Sea region and northeastern Turkey. Trends in drought intensity and crop growth are related to climate changes. The results suggest more frequent, intense and long-lasting droughts in the country particularly along the western and southern coasts under future climate conditions. A shift of climate classes towards drier conditions is also projected for the western, southern and central regions during the 21st century. Evaluating the role of the climate change trends in crop production reveals significant decreases in yield and shortened growth seasons for first- and second-crop corn, a likely result of high temperatures and water stresses. In addition to rising temperatures and declining precipitation, increasing frequency, severity and duration of drought events may significantly affect food production and socio-economic conditions in Turkey. Our results may help policy makers and relevant sectors to implement appropriate and timely measures to cope with climate-changeinduced droughts and their effects in the future.
\end{abstract}

KEY WORDS: Regional climate model $\cdot \operatorname{RegCM} 3 \cdot$ Climate change $\cdot$ Drought indices $\cdot$ Agriculture $\cdot$ Crop growth model $\cdot$ Corn · Turkey

Resale or republication not permitted without written consent of the publisher

\section{INTRODUCTION}

Turkey has experienced a notable rise in temperature and decrease in precipitation during the last few decades, as well an increase in minimum temperatures in winter and minimum and maximum temperatures in spring and summer (e.g. Türkeş \& Sümer
2004). Drought has become a recurring phenomenon in Turkey and semi-humid (semi-dry) drought classes have shifted to semi-dry (dry) conditions in the Aegean, Mediterranean and Central Anatolia regions (Türkeş 2003). As a consequence of drier conditions in recent decades, annual minimum, maximum and mean stream flows of Turkish rivers show significant 
decreasing trends for most basins, particularly in the western part of Turkey (Kahya \& Kalayci 2004, Topaloglu 2006). Since surface water and groundwater resources are limited in the Aegean, Thracian and Central regions, there is intense competition for water between sectors, particularly in western regions. Concomitant indications of increasing water demand have been noted in the central Anatolia (Türkeş et al. 2009) and southeastern Anatolia (Tonkaz 2008) regions of Turkey.

Less rain and more droughts can bring crop failure and economic losses. Occurring in tandem with significant drought events, water shortages for all water-using sectors have reached their critical points, and up to $100 \%$ yield losses have also been reported in Turkey (e.g. Türkeş \& Erlat 2005). The cost of drought to the Turkish agricultural sector in a recent drought year, 2007, was estimated at about $€ 2.3-2.5$ billion (Oral 2008). Cereals, mainly wheat, barley and corn, are grown under both rain-fed and irrigated conditions throughout the country. Irrigated agriculture consumes $75 \%$ of total freshwater withdrawals with a notably low efficiency (Topcu 2011). Owing to either less rainfall in winter or spring or irrigation deficits in summer, climate change-induced water shortages can diminish plant growth and harm yields of rain-fed and irrigated crop production.

Development of appropriate adaptation strategies to address climate change is typically based on the results of projections of future climate conditions including those associated with extreme events, which allows evaluations of the effects of climate change on water availability and agricultural productivity in a particular country to be performed. Climate change simulation efforts using regional climate models in Turkey date back only a few years and are very rare (Önol 2007, Demir et al. 2008, Topcu et al. 2008, Önol \& Semazzi 2009, Sen 2009). Turkish researchers most frequently use the regional climate model International Centre for Theoretical Physics (ICTP)-RegCM. Depending on the selected general circulation models (GCMs) for boundary conditions and scenarios considered, the simulation results of these studies show temperature increases of 2.5 to $4.5^{\circ} \mathrm{C}$ throughout the country by the year 2100 ; the highest temperature increases are projected for the Aegean and eastern Anatolian regions (Önol 2007, Demir et al. 2008). A projected decline in winter precipitation by about 20 to $50 \%$ (Önol 2007 , Demir et al. 2008) in important agricultural regions, such as the Aegean, Mediterranean and southeastern Anatolian regions, may worsen the Turkey's climatic as well as socio-economic conditions. Recent studies (e.g. Tezcan et al. 2007) also indicate substantial decreases in both surface water and groundwater resources in southern Turkey.

Droughts and floods are among the world's costliest natural disasters, affecting a very large number of people each year (Wilhite 2000), and are expected to occur more often under global warming (Trenberth et al. 2004); it is therefore important to monitor them and predict their variability. Only a few studies deal with the probability of drought occurrence in Turkey (i.e. Türkeş 1999, Türkeş \& Tatli 2009); these assessments were made by using probability tests with historical drought statistics. Thus, the climate change projections, particularly those performed with highresolution climate models, have not yet been used for future drought investigations. Effects of climate change on crop productivity can be projected by using crop simulation models run with a control (reference) and a projected future climate (e.g. Rosenzweig \& Parry 1994, Wolf \& Van Diepen 1995, Easterling et al. 2007). Also, a very limited number of studies have dealt with the effects of climate change on crop water requirement (Topcu et al. 2008) and crop yield (Sen 2009) in Turkey. Hence, the objectives of this study are to (1) investigate the potential role of global warming on the future climate over Turkey, (2) analyse the historical and predicted droughts with regard to their spatial and temporal dimensions as well as potential intensity, frequency and duration, respectively, and finally (3) assess the potential effect of predicted changes in climate on first- and second-crop corn grown throughout the country by using a case study in a typical agricultural region in Turkey.

\section{DATA AND METHODS}

\subsection{Climate simulations}

The ICTP's Regional Climate Model system version 3 (RegCM3) (Pal et al. 2007) has been used to downscale reference (1961-1990, RF) and future (20712100, A2) scenario simulations. RegCM3 was run at $20 \mathrm{~km}$ horizontal resolution and with 18 levels in the vertical. The atmospheric component of the model is coupled with the Biosphere-Atmosphere Transfer Scheme (BATS; Dickinson et al. 1993). RegCM3 uses the sub-grid explicit moisture scheme SUBEX (Pal et al. 2000) for large-scale precipitation, and the Grell (1993) convective scheme with the Arakawa \& Schubert (1974) closure formulation has been adapted. The National Aeronautics and Space Agency 
(NASA), National Center for Atmospheric Research (NCAR) finite-volume element global model fvGCM with a horizontal grid interval of $1^{\circ}$ latitude and $1.25^{\circ}$ longitude and 18 vertical levels was used as driving data to produce the lateral boundary and initial conditions for the RF and A2 RegCM3 simulations (Jones et al. 2001, Coppola \& Giorgi 2005). The A2 scenario describes a highly heterogeneous world with a continuously increasing global population and regionally oriented economic growth (Nakicenovic et al. 2000). The observed climate data set from the Climate Research Unit (CRU), with a grid resolution of $0.5^{\circ} \times$ $0.5^{\circ}$, was compared with the RegCM3-RF simulations to validate the model.

\subsection{Drought analysis}

The Standardized Precipitation Index (SPI), the Percent of Normal Index (PNI) for precipitation and Erinç's Aridity Index (Im) for a 12 mo time scale were used to assess the drought characteristics for 51 cities representing different geographical features and precipitation regimes (Türkeş 1998) in Turkey (Fig. 1; city/station abbreviations given in Table 1). The time series of simulated monthly precipitation and average maximum temperatures of RF and A2 periods were acquired from the nearest grid point of each city and used for the calculation of 3 different drought indices. In addition to basic verification of the RegCM3 with regard to capturing capability for the climate variables (e.g. precipitation and maximum temperature), which were also used in the calculation of drought indices, we carried out another verification study for drought indices. For this purpose, the climate simulation results of RegCM3 driven by the European Centre for Medium-Range Weather Forecasts (ECMWF) 40 yr reanalysis (ERA40) were used for calculation of 3 drought indices. Those were compared with the observed station (cities) data for the period from 1961 to 1990.

The SPI is a probability index that measures drought based on the degree to which precipitation on a given time scale (12 mo for the present study) and geographic area (e.g. county, watershed) diverges from the historical median (McKee et al. 1993, 1995). It is calculated as follows:

$$
\mathrm{SPI}=\left(X_{i}-\bar{X}\right) / \sigma
$$

where $X_{i}$ is the precipitation, $\bar{X}$ is the arithmetic mean and $\sigma$ is the SD of the series.

Generally, precipitation series are not normally distributed. Therefore, the monthly time series of precipitations for a $30 \mathrm{yr}$ period (i.e. 1961-1990) are fitted with a gamma probability density function to a given frequency distribution of precipitation totals for a grid point. The gamma probability density function parameters are estimated for the grid points nearest to each city, both for $12 \mathrm{mo}$ and for each month of the year. We performed SPI analysis by fol-

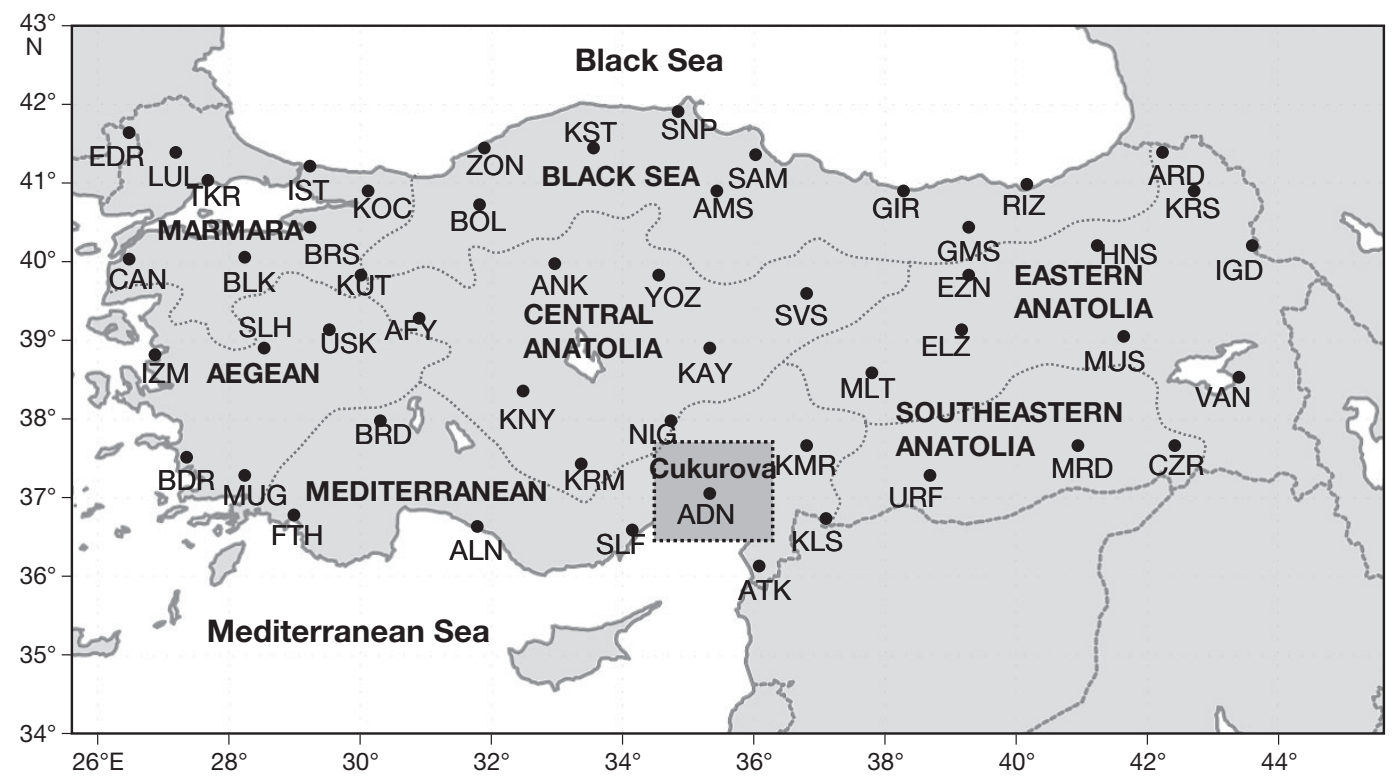

Fig. 1. Geographical regions of Turkey. Circles show the location of observation stations used for drought analysis and the shaded frame indicates the location of the case study area, the Cukurova District. Abbreviations in Table 1 
lowing the procedure and steps described in detail by Guttman (1999) and Strzepek et al. (2010) and using software developed by Türkeş \& Tatli (2009). Because the SPI is normalized, wetter and drier climates can be represented the same way, and wet periods can be monitored with the SPI. The period with a negative SPI value (indicates less than median precipitation) is defined as 'dry'; the month the index value drops to negative is considered the start of a drought and the month the index increases to positive values signals the end of a drought (McKee et al. 1995). The index values and accordingly the drought classes for the SPI are shown in Table 2.

The PNI is one of the simplest measurements of rainfall for a location and is obtained as a percentage by dividing the amount of precipitation for a specific (12 mo) period by the average. Normal precipitation for a specific location is considered to be $100 \%$. The PNI is calculated as follows:

$$
\mathrm{PNI}=\frac{P i}{\bar{P}} \times 100
$$

where $P i$ is the actual amount (mm) of precipitation and $P$ is the amount of the long-term average $(\mathrm{mm})$. Index values and drought classes for the PNI are listed in Table 3. A period is considered 'dry' if a PNI value is continuously below the threshold value. The first value below the threshold is taken as the 'start of a drought' and the first value above the threshold thereafter is considered the 'end of a drought' (Hayes 1998).

The drought occurrences (percentage of time) for 51 cities have been identified based on the frequency of the events for each drought category by using the SPI and the PNI results. Drought risk and effects are dependent on a combination of the frequency, intensity, time scale and spatial extent of drought, which also define the physical nature of droughts. Since the drought analyses were assessed for the selected points in our case cities, and also because the time scale was unique and constant (12 mo), a drought effect can be determined as a function of the intensity and the frequency of drought events. Accordingly, we developed an indicator called the total drought effect (TDE), formulated as Eq. (3) below, to facilitate a meaningful comparison of the modeled drought events by using the SPI and PNI indices from the RF and A2 periods. The consecutive effect of droughts has not been included in this approach; however, it is assumed the effect of frequency on drought risk is stronger than that of intensity. The TDE is calculated as follows:
Table 1. Station/city abbreviations

\begin{tabular}{|c|c|c|c|}
\hline $\begin{array}{l}\text { Abbrev- } \\
\text { iation }\end{array}$ & $\begin{array}{l}\text { Station/city } \\
\text { name }\end{array}$ & $\begin{array}{l}\text { Abbrev- } \\
\text { iation }\end{array}$ & $\begin{array}{l}\text { Station/city } \\
\text { name }\end{array}$ \\
\hline $\mathrm{ADN}$ & Adana & KLS & Kilis \\
\hline AFY & Afyon & KMR & Kahramanmaraş \\
\hline ALN & Alanya & KNY & Konya \\
\hline AMS & Amasya & KOC & Kocaelı \\
\hline ANK & Ankara & KRM & Karaman \\
\hline ARD & Ardahan & KRS & Kars \\
\hline ATK & Antakya & KST & Kastamonu \\
\hline BDR & Bodrum & KUT & Kütahya \\
\hline BLK & Balikesır & LUL & Lüleburgaz \\
\hline BOL & Bolu & MLT & Malatya \\
\hline BRD & Burdur & MRD & Mardin \\
\hline BRS & Balikesır & MUG & Muğla \\
\hline CAN & Çanakkale & MUS & MuŞ \\
\hline CZR & Cizre & NIG & Niğgde \\
\hline EDR & Edırne & RIZ & Rize \\
\hline ELZ & Elazĭ̆ & SAM & Samsun \\
\hline EZN & Erzincan & SLF & Silıfke \\
\hline FTH & Fethiye & SLH & Salıhlı \\
\hline GIR & Giresun & SNP & Sinop \\
\hline GMS & Gümüşhane & SVS & Sivas \\
\hline HNS & Hinis & TKR & Tekırdağ \\
\hline IGD & Iğdir & URF & Urfa \\
\hline IST(GZT) & İstanbul & USK & Uşak \\
\hline IZM & İzmır & VAN & Van \\
\hline \multirow[t]{2}{*}{ KAY } & Kayserı & YOZ & Yozgat \\
\hline & & $\mathrm{ZON}$ & Zonguldak \\
\hline
\end{tabular}

Table 2. Drought classes and equivalent standardized precipitation index (SPI) ranges

\begin{tabular}{|lc|}
\hline Drought class & SPI \\
\hline Extremely wet & $\geq 2.0$ \\
Very wet & 1.5 to 1.99 \\
Moderately wet & 1.0 to 1.49 \\
Near normal & -0.99 to 0.99 \\
Moderately dry & -1.0 to -1.49 \\
Severely dry & -1.5 to -1.99 \\
Extremely dry & $\leq-2$ \\
\hline
\end{tabular}

Table 3. Percentage of normal precipitation for drought classes as related to number of months analyzed and the Percent of Normal Index (PNI) for precipitation used in the climate change simulation for Turkey

\begin{tabular}{|lcccc|}
\hline $\begin{array}{l}\text { No. of } \\
\text { months } \\
\text { analyzed }\end{array}$ & Normal & $\begin{array}{l}\text { Moderately } \\
\text { dry (watch) }\end{array}$ & $\begin{array}{c}\text { Severely dry } \\
\text { (warning) }\end{array}$ & $\begin{array}{c}\text { Extremely dry } \\
\text { (emergency) }\end{array}$ \\
\hline 1 & $>75$ & 65 to 75 & 55 to 65 & $<55$ \\
3 & $>75$ & 65 to 75 & 55 to 65 & $<55$ \\
6 & $>80$ & 70 to 80 & 60 to 70 & $<60$ \\
9 & $>83.5$ & 73.5 to 83.5 & 63.5 to 73.5 & $<63.5$ \\
12 & $>85$ & 75 to 85 & 65 to 75 & $<65$ \\
PNI & 1 & 2 & 3 & 4 \\
\hline
\end{tabular}


Table 4. Erinç's climate types corresponding to the aridity index (Im) and vegetation types (from Kutiel \& Türkeş (2005) based on Erinç (1965). Perhumid: permanently humid

\begin{tabular}{|lccc|}
\hline Climate types & Index $(\operatorname{Im})$ & Plant cover & Index class \\
\hline Severe arid & $<8$ & Desert & 1 \\
Arid & 8 to 15 & Desert like steppe & 2 \\
Semi-arid & 15 to 23 & Steppe & 3 \\
Semi-humid & 23 to 40 & Dry forest & 4 \\
Humid & 40 to 55 & Humid forest & 5 \\
Perhumid & $>55$ & Perhumid forest & 6 \\
\hline
\end{tabular}

$$
\mathrm{TDE}=\sum_{j=1}^{n}\left(D i_{j} \cdot D f_{j}^{2}\right)
$$

where $D i$ is the drought intensity and $D f$ is the drought frequency. TDE indicators are calculated for each city for both (RF and A2) periods, whereupon a positive difference between A2 and RF values is interpreted as an increase of drought risk and effect in the future.

Erinç's Aridity (Precipitation Efficiency) Index (Im) is based on precipitation and maximum temperature, which causes water deficiency due to evaporation, and is determined from the following equation:

$$
I m=\frac{P}{T_{\max }}
$$

where $P$ and $T_{\max }$ equal long-term averages of annual precipitation total $(\mathrm{mm})$ and annual maximum temperature $\left({ }^{\circ} \mathrm{C}\right)$, respectively. Erinç (1965) divided his index into 6 major classes by comparing results of the index with spatial distribution of vegetation formations over Turkey, as given in Table 4 .

\subsection{Simulation of crop yield}

We carried out a case study in the Cukurova District to assess the possible effects of climate change on plant growth and yield for first- and second-crop corn. Cukurova, located in the east Mediterranean region (Fig. 1), provides half the country's corn production, and its agricultural production is vulnerable to climatic change. We used the World Food Studies Crop Model, WOFOST (Boogaard et al. 1998), a 1-dimensional, mechanistic and site-specific crop model that simulates daily interactions with climate, soil and management, to determine growth, development and yield of corn crops. The model was designed to simulate 3 production levels. The potential yield production level is limited only by temperature, solar radiation and the specific physiological plant characteristics. At the water-limited production level (for either rain-fed or water shortage for irrigation conditions), the soil and plant water balance is also included in the simulation of crop growth, which takes into account the interactions between transpiration, stomata opening, $\mathrm{CO}_{2}$ assimilation and water uptake. The third production level is limited by nutrients.

Representative points mainly reflect differences in climate, topography and soil properties across the Cukurova Region. Weather input data used are daily rainfall, minimum and maximum temperatures, wind speed, global radiation and air humidity. Information about site-specific soil input parameters such as the $\mathrm{pF}$ curve (soil water retention), hydraulic conductivity at saturation, initial contents of total nitrogen, phosphorus and potassium and soil-limited rooting depth as well as management conditions such as sowing date, plant density, irrigation and fertilization management (i.e. method, amount, date) are taken from previous field and survey studies. Crop parameters used are weight of seed, temperature sums, photoperiod response and yield components of corn varieties that are widely used in the region. The crop model was first calibrated and then validated. A sensitivity analysis was also performed to reveal the role of different parameters and ensure the calibration quality.

Crop-modeling simulation experiments were performed for the RF, and RegCM3 A2 scenarios with (water-limited production level) and without (potential production level) the physiological effects of water deficit. State Hydraulic Works, the authority responsible for land and water resources development in Turkey, estimates a decrease of up to $30 \%$ of available water in Cukurova after 2030. Additionally, by considering the projected increasing effect of temperatures on evaporation and declining precipitation and increasing competition between water user sectors, we assumed a reduction by about $40 \%$ in water resource availability for the Cukurova District for the A2 period. Therefore, in addition to simulations representing potential yield production conditions, we applied different deficit irrigation scenarios by changing the number and interval as well as start and cut-off dates of irrigation to simulate the effects of climate change on both agricultural and hydrological drought-related water shortages (water-limited level). The difference in yield between the potential and water-limited levels has been interpreted as the effect of limited water availability on agriculture and changes in yield (stated as percentage), which is evaluated by comparing future crop yields to current yields (simulated for the RF period). 


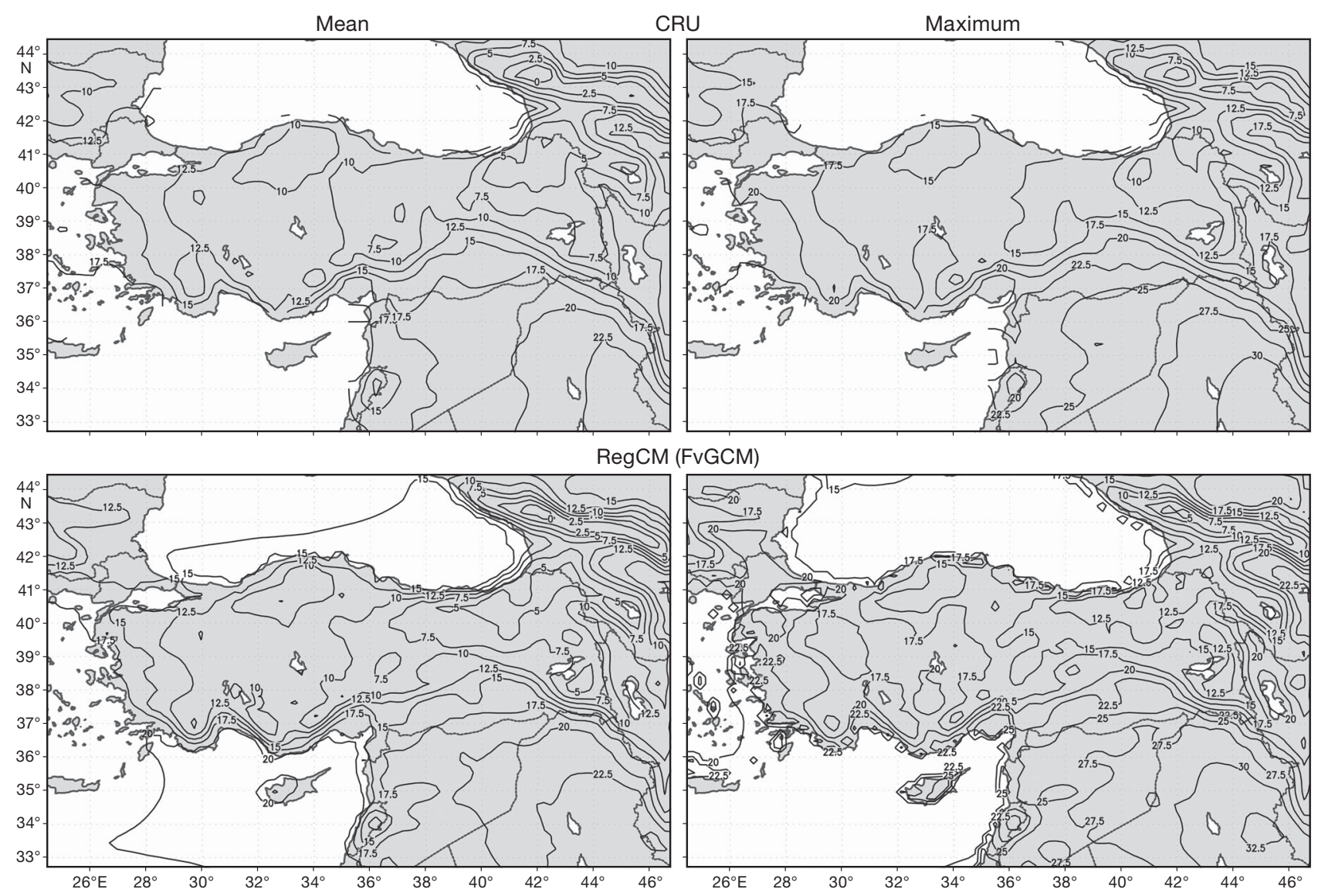

Fig. 2. Comparison of annual mean (left panels) and maximum (right panels) surface temperatures $\left({ }^{\circ} \mathrm{C}\right.$ ) between $\mathrm{CRU}$ (top panels) and RegCM3-fvGCM (bottom panels) for 1961-1990

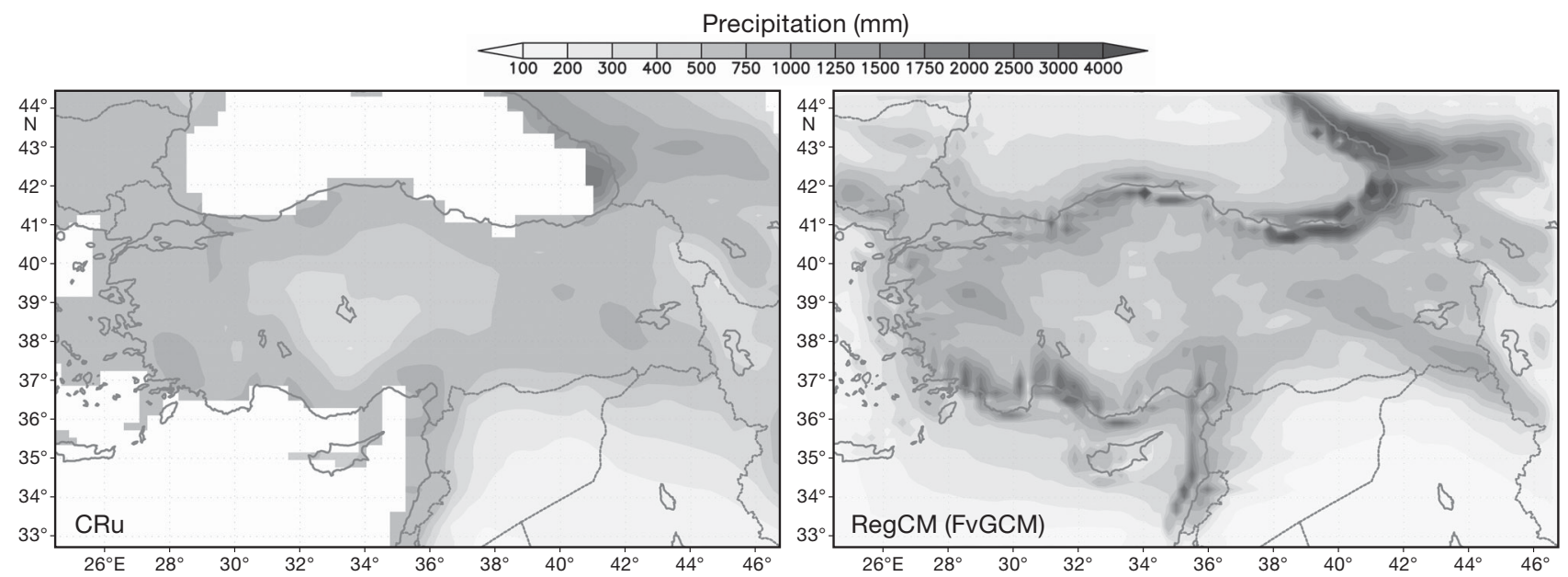

Fig. 3. Annual total preciptation (mm) comparison between CRU (left panel) and RegCM3-fvGCM (right panel) for 1961-1990

\section{RESULTS}

\subsection{Current and future climate: verification versus observations and projections}

The RegCM3 was able to successfully capture the mean temperature distribution throughout the year
(Fig. 2), although a cold bias of up to $2^{\circ} \mathrm{C}$ was noted over the mountainous areas. Maximum surface temperatures produced in the experiment are also in reasonable agreement with the observed climatology for winter and spring months (data not shown). However despite the well-captured distribution pattern, the temperatures are somewhat overestimated by about 
Table 5. Area-averaged (Turkey) long-term (1961-1990) differences between simulated data and data from the Climate Research Unit (RF minus CRU) for temperatures and precipitation. $T_{\max }$ : maximum temperature; $T_{\min }$ : minimum temperature; $T_{\text {mean }}$ : mean temperature

\begin{tabular}{|lrrrr|}
\hline Time period & $\begin{array}{r}T_{\max } \\
\left({ }^{\circ} \mathrm{C}\right)\end{array}$ & $\begin{array}{l}T_{\min } \\
\left({ }^{\circ} \mathrm{C}\right)\end{array}$ & $\begin{array}{c}T_{\text {mean }} \\
\left({ }^{\circ} \mathrm{C}\right)\end{array}$ & $\begin{array}{r}\text { Precipitation } \\
\left(\mathrm{mm} \mathrm{d}^{-1}\right)\end{array}$ \\
\hline Dec-Feb & 1.6 & 3.8 & 2.4 & 0.84 \\
Mar-May & -0.2 & 1.6 & 0.4 & 0.25 \\
June-Aug & 2.6 & 3.1 & 2.4 & -0.55 \\
Sep-Nov & -1.1 & 2.1 & -0.1 & 0.34 \\
Full year & 0.7 & 2.6 & 1.3 & 0.22 \\
\hline
\end{tabular}

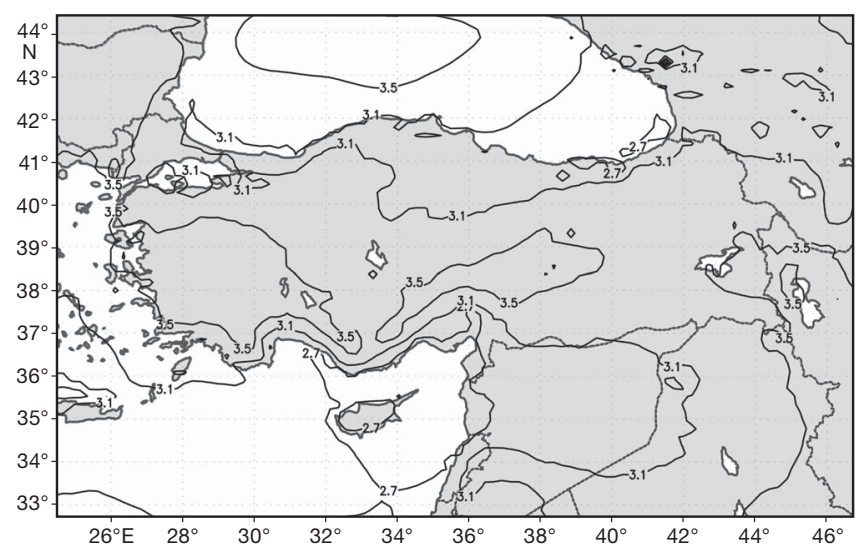

Fig. 4. Annual maximum temperature change (A2 minus RF; ${ }^{\circ} \mathrm{C}$ ) over Turkey

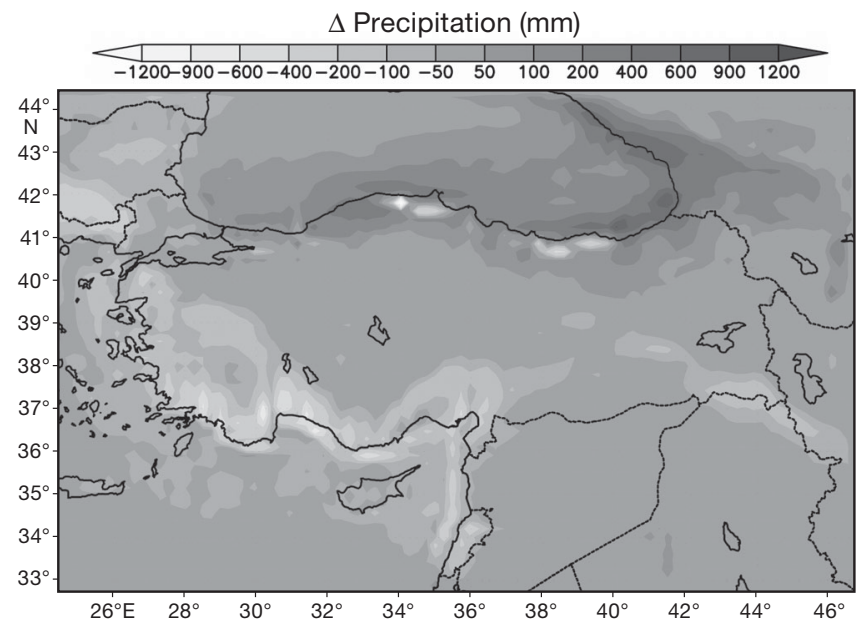

Fig. 5. Annual total precipitation change (A2 minus RF) over Turkey

2 to $4^{\circ} \mathrm{C}$ in northern and eastern parts of the country, in particular, for the summer months over Turkey (data not shown). Annual mean of maxima exhibited a warm bias of up to $2^{\circ} \mathrm{C}$ around the coastline in the Aegean, Mediterranean and Thracian regions, as well as in the southern part of southeast Anatolian region (Fig. 2). With regard to annual precipitation series the model results agree well with the CRU observations (Fig. 3). According to country averages of seasonal and annual means of the $30 \mathrm{yr}$ (19611990) period, the differences between the simulated (RegCM3) and observed (CRU) climate parameters (Table 5) are lower during the spring and autumn than during the summer and winter seasons; annual totals as a country average was reasonably well represented by the model.

Climate change trends in maximum temperature and annual total precipitation used for the calculation of drought indices are presented in Figs. 4 \& 5, respectively. The changes refer to the difference between $30 \mathrm{yr}$ means in the A2 scenario and RF simulations. The experiment simulates an increase in annual mean temperatures by between 2.7 and $3.5^{\circ} \mathrm{C}$ over Turkey (data not shown), while expected changes show great seasonal variation. The Eastern Anatolia region, the eastern Black Sea and the northern portion of the Southeastern Anatolia region will probably experience warmer summers $\left(3.4\right.$ to $\left.3.5^{\circ} \mathrm{C}\right)$; however, an increase in summer temperatures by about $5.1^{\circ} \mathrm{C}$ over the Aegean region indicates heat waves. Annual maximum and minimum temperatures are expected to increase, although the increases are obvious in western Turkey in summer and eastern Turkey in the winter season. Our climate projections indicate increases of minimum temperatures by about $3^{\circ} \mathrm{C}$ for the entire country (data not shown), while maximum temperatures are expected to rise annually by $3.1^{\circ} \mathrm{C}$ in the north and west of Turkey and by $3.5^{\circ} \mathrm{C}$ in the east and south (Fig. 4).

A notable decrease in precipitation (150 to $300 \mathrm{~mm}$ ) is simulated in winter around the southern coastal region of Turkey, particularly across the eastern Mediterranean Sea; however, almost no change (a slight decrease partially in the northern and eastern parts of the country) is expected for summer precipitation (data not shown). Notably, an area of considerable precipitation decrease extends into the Cukurova District, but is blocked by the Taurus Mountains to the north. The experimental results project precipitation decreases of around $25 \%$ in winter in the Aegean, Mediterranean and southeastern regions, and to vary between 60 and $150 \mathrm{~mm}$ (about $20 \%$ of total) annually in the Marmara, Aegean, Mediterranean and southeastern Anatolian regions (Fig. 5). Projected increases in annual total precipitation are predicted to reach up to $400 \mathrm{~mm}$ ( $25 \%$ ) over the eastern part of the Black Sea and northern part of the eastern Anatolia regions. 

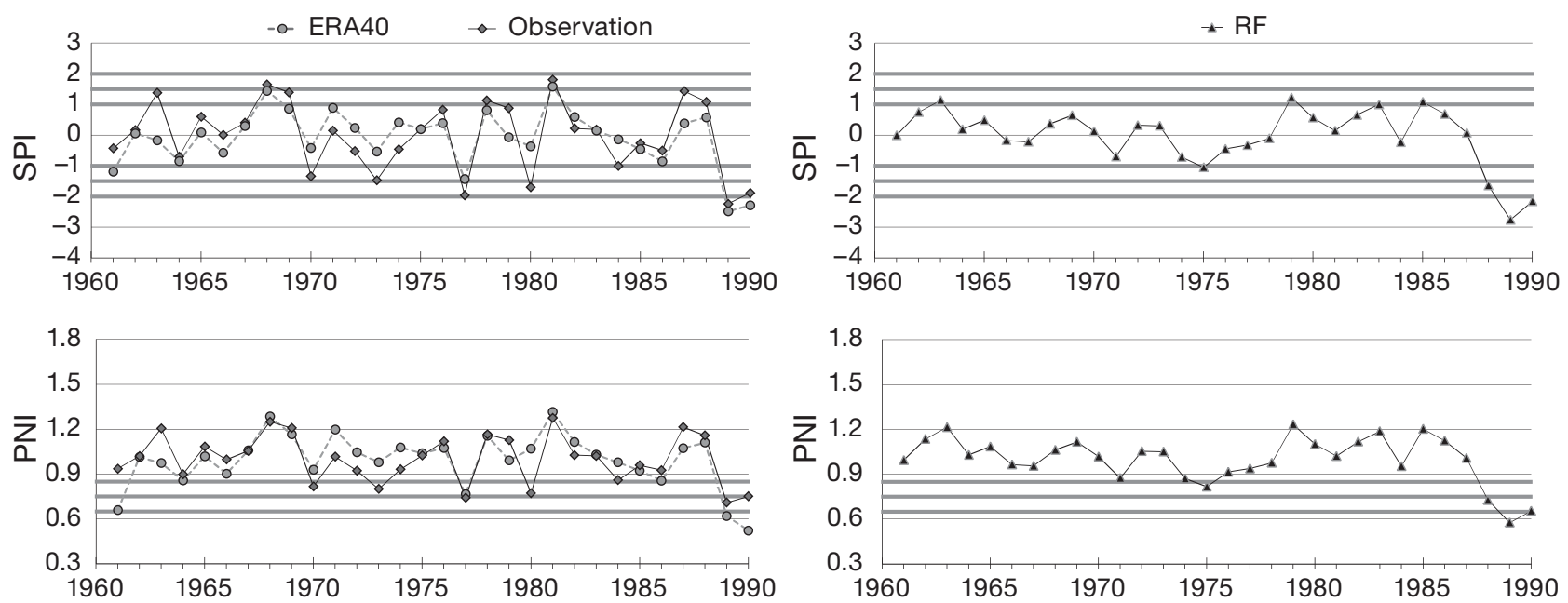

Fig. 6. Comparison of simulated using ERA40 reanalysis data and observed SPI (top left) and PNI (bottom left) over Turkey. Graphs on the right side panels show the interannual variability of SPI (top right) and PNI (bottom right) values simulated using fvGCM data for the reference period (RF)

Table 6. Differences for 1961-1990 between simulated and observed Erinç's aridity indices (Im) and Im classes for representative cities of different regions in Turkey

\begin{tabular}{|lccccrc|}
\hline \multirow{2}{*}{ Station } & \multicolumn{2}{c}{ Observed } & \multicolumn{2}{c|}{ Simulated } & \multicolumn{2}{c|}{ Simulated - Observed } \\
& Im & Im_Class & Im & Im_Class & $\Delta$ Im & $\Delta$ Class \\
\hline Ankara & 16.6 & 3 & 17.8 & 3 & 1.2 & 0 \\
Burdur & 16.4 & 3 & 26.6 & 4 & 10.2 & 1 \\
Istanbul & 27.5 & 4 & 40.6 & 5 & 13.1 & 1 \\
Izmir & 23.9 & 4 & 34.4 & 4 & 10.5 & 0 \\
Kastamonu & 20.0 & 3 & 23.9 & 4 & 3.9 & 1 \\
Malatya & 16.4 & 3 & 18.0 & 3 & 1.6 & 0 \\
Mardin & 28.4 & 4 & 13.2 & 2 & -15.2 & -2 \\
\hline
\end{tabular}

nature of the input data. Im values, calculated based on simulation results of the RegCM3-ERA40, also agreed with those calculated from the observed climate parameters at stations in central, northern and eastern Anatolia as well as at the country level during 1961 to 1990 (Table 6; each city in the table represents a region shown in Fig. 1). The Im values based on simulated and observed climate data differ from each other for Burdur, Istanbul and Kastamonu where more humid climate conditions

\subsection{Characteristics of droughts}

Both drought indices, the SPI and PNI, calculated by using simulation results of RegCM3 driven by the ECMWF 40 yr reanalysis data (RegCM3-ERA40), showed reasonably good agreement in terms of severity and time of the drought events with the observation data at both station (data not shown) and country (Fig. 6) scales. Although the fvGCM driven simulation is not expected to reproduce the actual sequence of the drought indices, we present 2 separate, additional panels (Fig. 6) to examine whether the interannual variability of the indices (an important drought characteristic) resembles the observed conditions. As shown in Fig. 6, the interannual variability was captured surprisingly well by the RegCM3 driven with fvGCM for both indices (SPI and PNI) despite the limitations associated with the were estimated compared with the observations. This deviation may be related to an underestimation of maximum temperatures for these 3 cities (data not presented). The Im calculation according to RegCM3-ERA40 simulated data for Mardin, however, resulted in a drier climate (desert-like steppe, 2) compared with the calculated index based on observations (dry forest, 4) (Table 6).

Results of SPI calculations indicated a doubling or even tripling of the frequency of drought events in cities such as Edirne (EDR), Canakkale (CAN), Izmir (IZM), Mugla (MUG), Burdur (BRD), Fethiye (FTH), Silifke (SLF), Adana (ADN) and Kilis (KLS) (cities listed according to their location in Fig. 1, from the northwest through the west and southwest to the southeast). With respect to the PNI results, we can expand the above list with 3 more cities: Salihli (SLH) in the Aegean, Malatya (MLT) in eastern Anatolia 

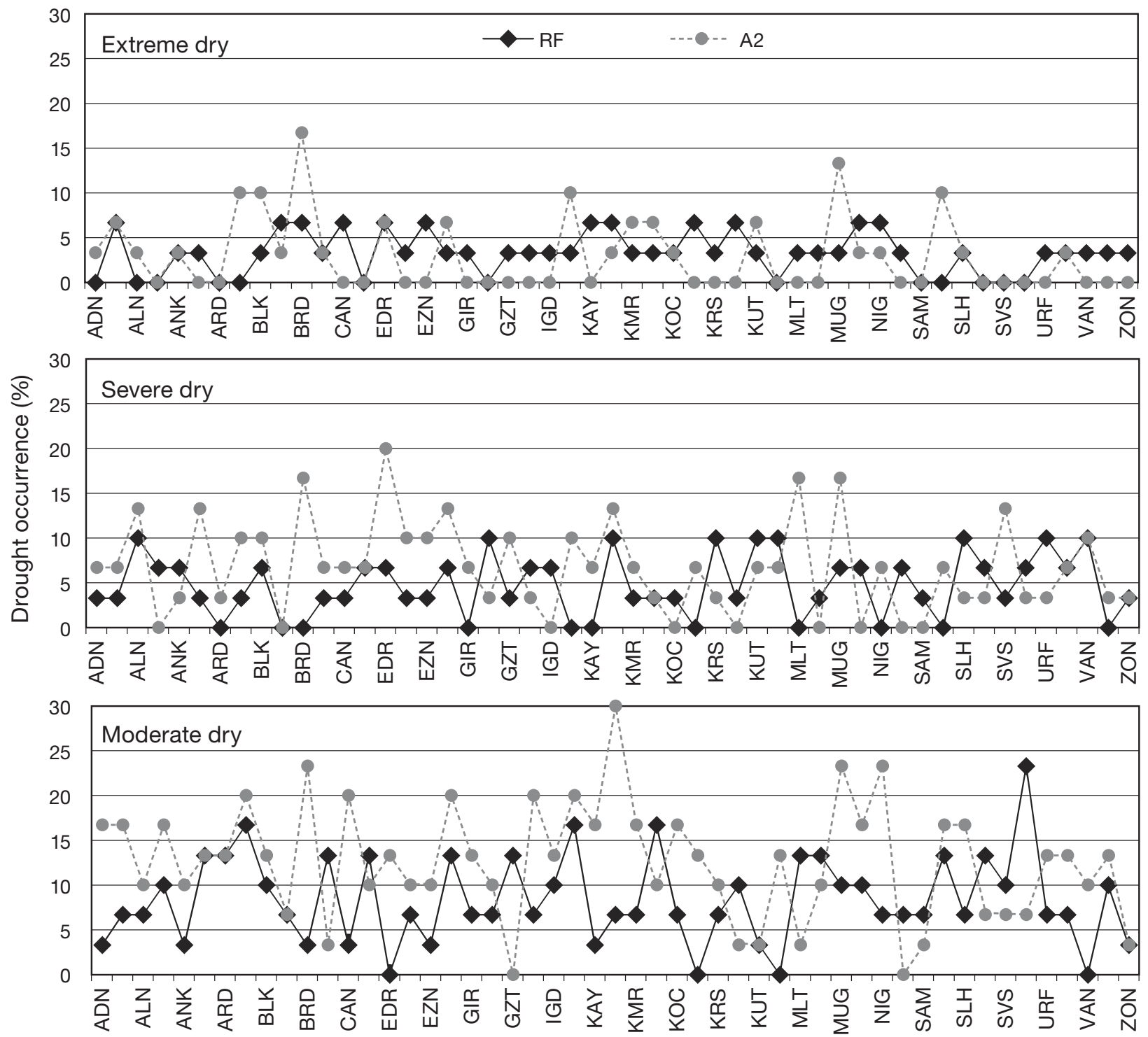

Fig. 7. Drought occurrences in different stations over Turkey during the reference (RF) and future (A2) periods based on the SPI. Station/city abbreviations on $x$-axes given in Table 1

and Urfa (URF) in southeastern Anatolia. In fact, out of the total set of 51 cities, increases in drought frequency were detected in 33 and 34 of them, based on results obtained by SPI and PNI, respectively.

The drought occurrence shown in Figs. 7 to 9 refers to the ratio between number of drought events (frequency) and the whole period (30 yr) considered for each drought severity class. Out of 51 cities, 27 of them, including those over large parts of the Aegean, Mediterranean and central, eastern and southeastern Anatolia regions, are expected to face climate conditions with more frequent events of 'moderate drought'. Occurrences of 'extreme drought' conditions are also projected to increase in 12 cities, mostly located in Aegean and Mediterranean regions of Turkey. Drastic increases in 'severe drought' conditions are simulated to occur especially in the coastal areas of western and southwestern Turkey. Results of PNI calculations (Fig. 9) demonstrate similar climate change trends. Considering all 3 drought severity categories (moderate, severe and extreme) together, both drought indices (SPI and PNI) indicate substantial increases in the incidence of drought over the entire Aegean and southeastern Anatolia regions and western and central parts of the Mediterranean region during almost half of the A2 period modelled. In the simulation results, under the future climate conditions southeastern Anatolia will receive less rainfall 


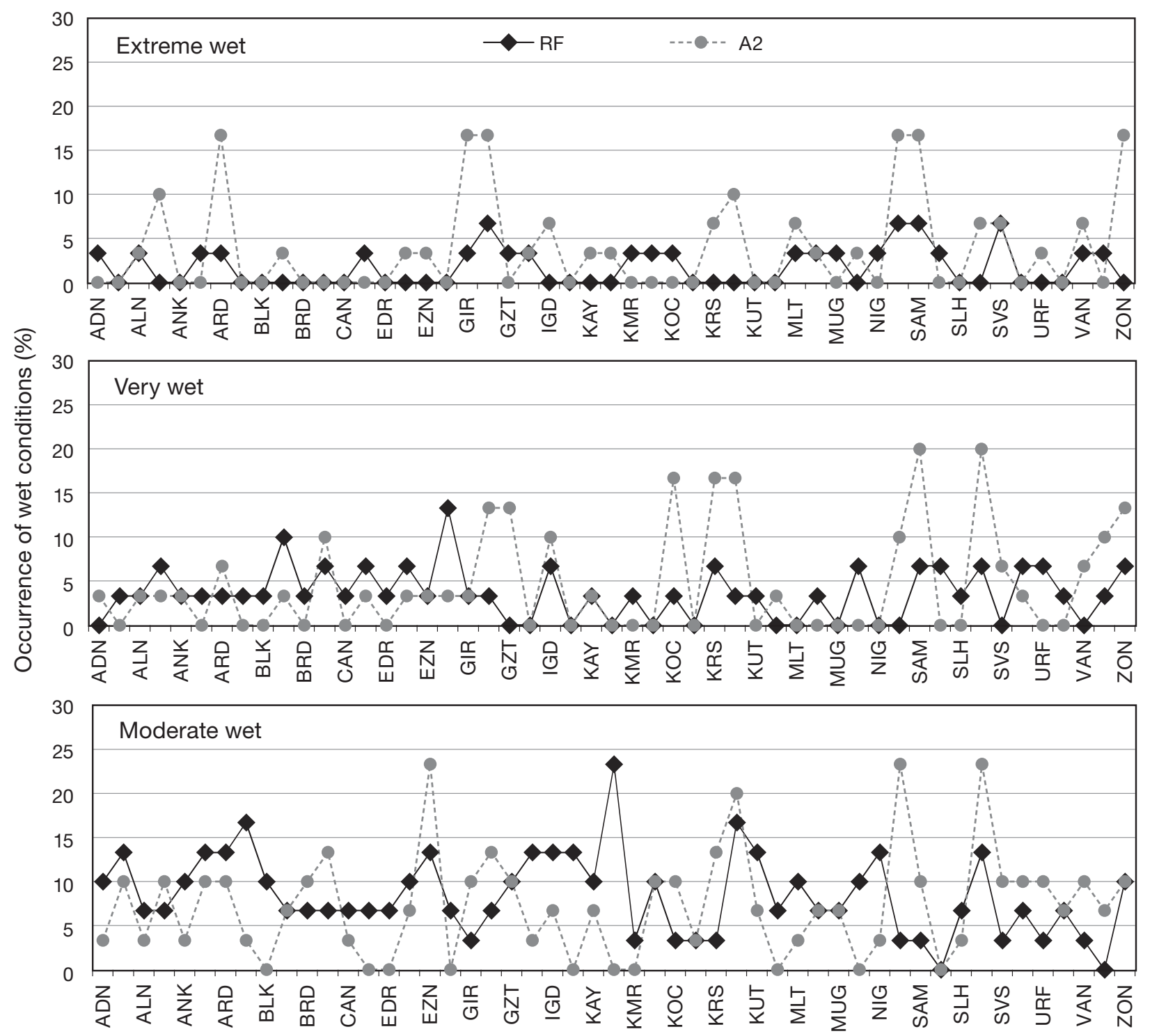

Fig. 8. Occurrences of wet conditions in different stations over Turkey during the reference (RF) and future (A2) periods based on SPI. Station/city abbreviations given in Table 1

compared with the other regions in the country; consequently the values of both drought indices indicated that under the simulated future climate conditions, moderate droughts will occur more often in the region. According to the results of simulation of the future climate conditions over Turkey, as shown in Figs. $7 \&$, the country will experience worsened drought conditions in several stations of this region due to increases in the number and severity of droughts and decreases in wet conditions (with regard to both severity and number of occurrence). The climate change projection also indicates a higher occurrence of moderate and severe droughts in half of the eastern Anatolia region during 2071-2100 versus
1961-1990. Based on SPI data, we conclude that the wet conditions currently observed over some parts of the country are unlikely to occur in the future in most cities of the Mediterranean and Aegean regions (Fig. 7). Nevertheless 10 cities, mostly located in the Black Sea and eastern Anatolia regions, may experience wetter conditions in the future compared with the RF period. Our SPI experimental results (Fig. 8) indicate a 3- to 5 -fold increase in the frequency of wet conditions for cities including Sinop (SNP), Samsun (SAM), Giresun (GRS), Gümüshane (GMS), Rize (RIZ) and Kars (KRS).

To estimate the combined effect of climate change on drought intensity and frequency, the TDE of the 

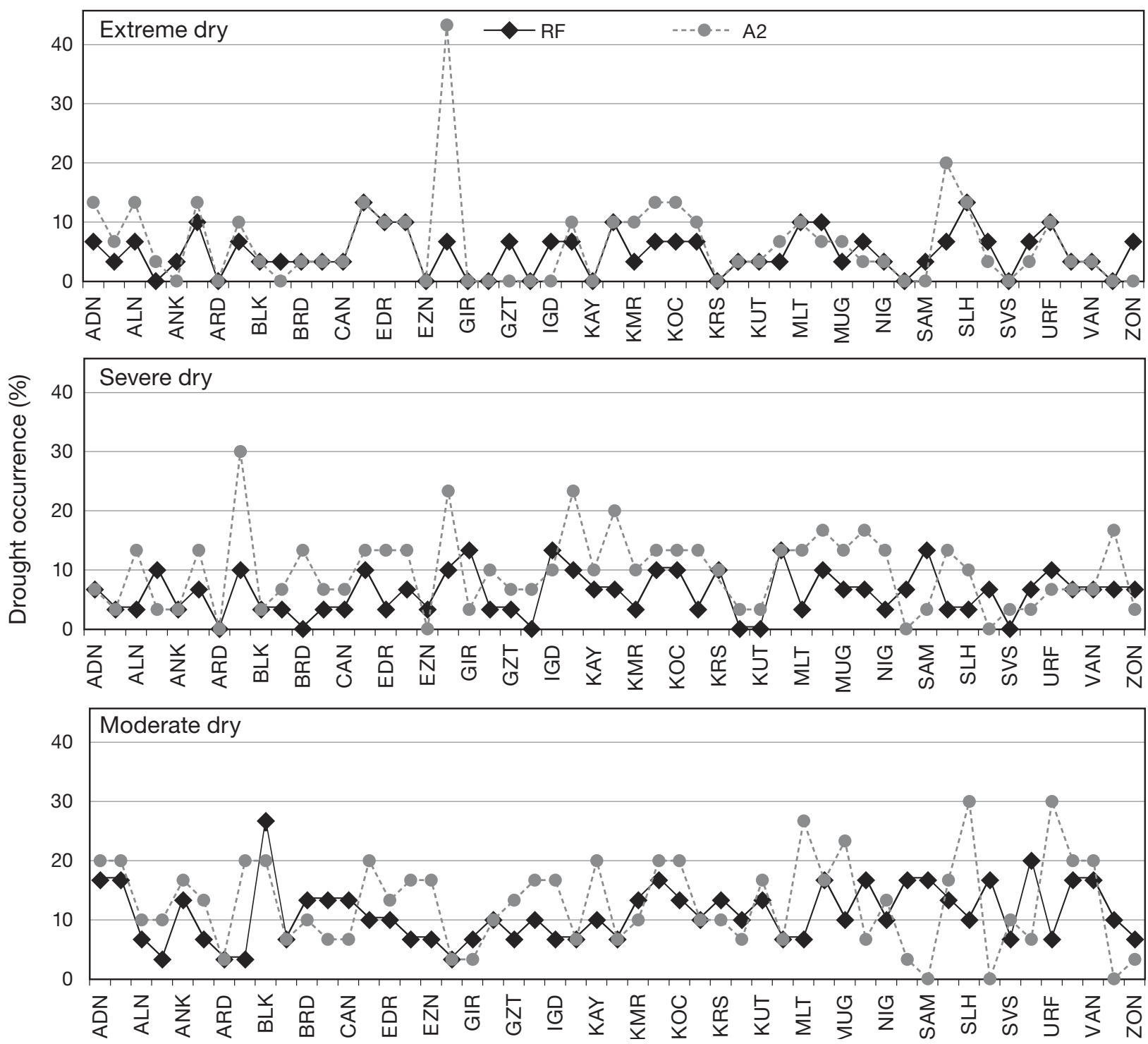

Fig. 9. Drought occurrences in different stations over Turkey during the reference (RF) and future (A2) periods based on the PNI for precipitation. Station/city abbreviations on $x$-axes given in Table 1

climate change values was calculated and is presented in Fig. 10 for each city. In this analysis we use 3 levels of TDE consistent with SPI and PNI classes: moderate (TDE $<50$ ), severe (TDE 50-100) and extreme (TDE > 100). As shown on both maps (Fig. 10), the Black Sea region becomes predominantly wet based on PNI results, although the predicted magnitude of change seems to be lower based on SPI simulations. According to our predictions, the drought effects will be strongest in the Aegean and Mediterranean regions, however, and have a considerable northward expansion.

Erinç's Im perfectly depicts similar climatic conditions with the other 2 drought indices. The trends projected indicate an expansion of the 'arid' areas, particularly in the Southeast Anatolia, as well as a shift in the climate class from 'semi-humid' towards 'semi-arid' in the cities including Adana, Elazig (ELZ), Hatay (ANT), Karaman (KRM), Kars, Kayseri (KAY), Kilis, Mugla and Yozgat (YOZ). A significant transition from 'humid' towards 'semi-humid' is also simulated for the Aegean (Izmir), Marmara (Canakkale, Edirne, Balikesir [BLK]), Mediterranean (Burdur, Silifke, Kahramanmaras [KMR]) and central Anatolia (Afyon [AFY]) regions. The change towards drier conditions for Kars despite a projected increase in precipitation (Fig. 5) may be considered as a consequence of a significant increase of maximum tem- 

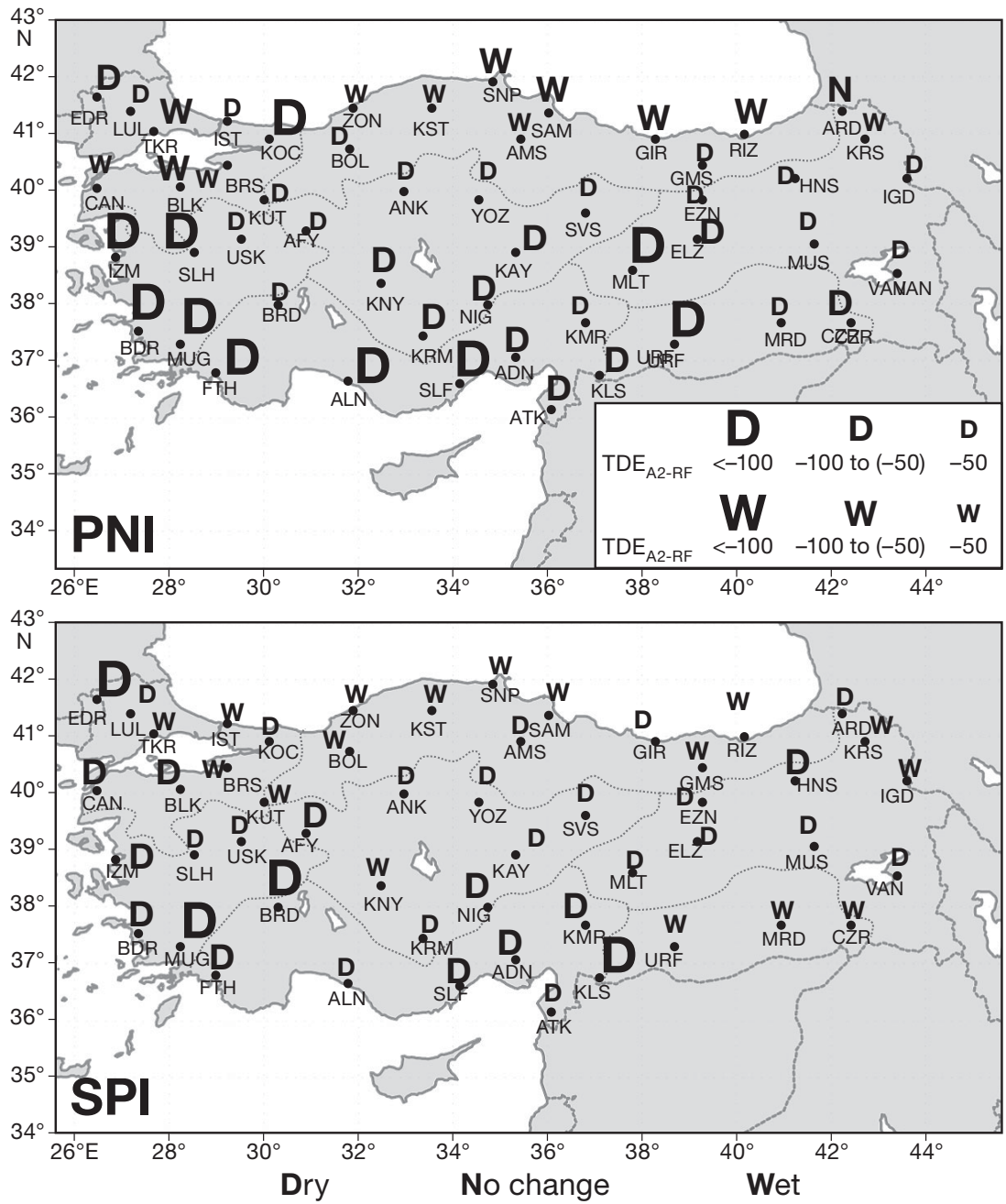

Fig. 10. Projected changes in total drought effects (i.e. A2 minus RF) $\left(\mathrm{TDE}_{\mathrm{A} 2-\mathrm{RF}}\right)$ based on the SPI and the PNI in Turkey. The letter D indicates a change towards drier conditions while $\mathrm{W}$ stands for a change towards wetter conditions. The different sizes of ' $\mathrm{D}$ ' and ' $\mathrm{W}$ ' refer to level of change (see scale in upper right); ' $\mathrm{N}$ ' indicates no change

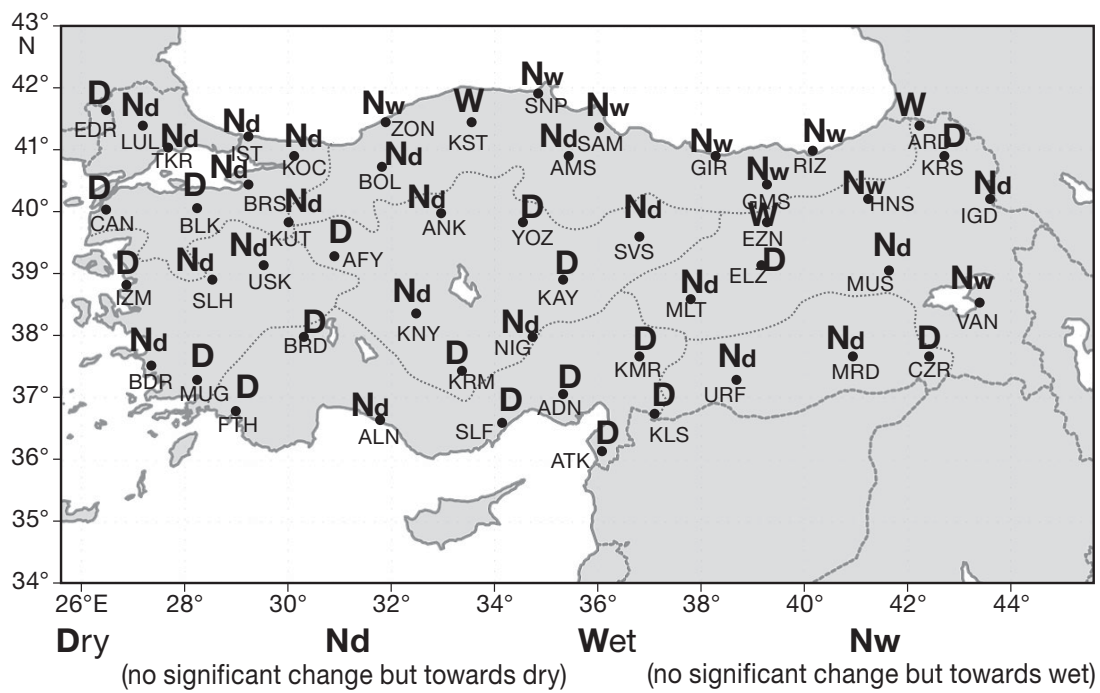

perature predicted (Fig. 4) in the experiment for this part of the eastern Anatolia region. According to our study results no change with regard to climate class is estimated for 29 of 51 cities; however, an increased index value was determined for 21 of those 29 cities, which are labelled ' $\mathrm{Nd}$ ' on Fig. 11. Under the simulated future climate conditions, the index values decrease slightly in the remaining 8 cities located in the coastal Black Sea region. Most of the desert areas with arid climate in Turkey are located in the southeastern and central Anatolia regions. Owing to limited precipitation as well as increased temperatures, these areas are likely to expand, while a corresponding retreat of the semiarid and semi-humid areas is projected for the interior Mediterranean and Aegean regions.

\subsection{Effect on crop yield}

After performing a sensitivity analysis testing 11 variables, the parameters emerging as most relevant were iteratively modified for the best possible calibration of the WOFOST model. We used observations with regard to climate, soil and plant genetic information as well as crop management from previous field trials carried out in 4 different locations across the Cukurova region in the years 1991, 1993, 2004 and 2005 for calibration. The calibrated model was validated by using another set of data gathered from field experiments conducted in the years 1992, 1994, 1996 and 2005. One example from the

Fig. 11. Projected changes in Erinç's aridity index $(\operatorname{Im})$ in Turkey. The letters ' $\mathrm{D}$ ' and 'W' indicate a change towards drier and wetter conditions, respectively. ' $\mathrm{Nd}$ ' and ' $\mathrm{Nw}$ ' indicate no changes of aridity class; however, changes in magnitude of value towards dry or wet conditions were still evident 

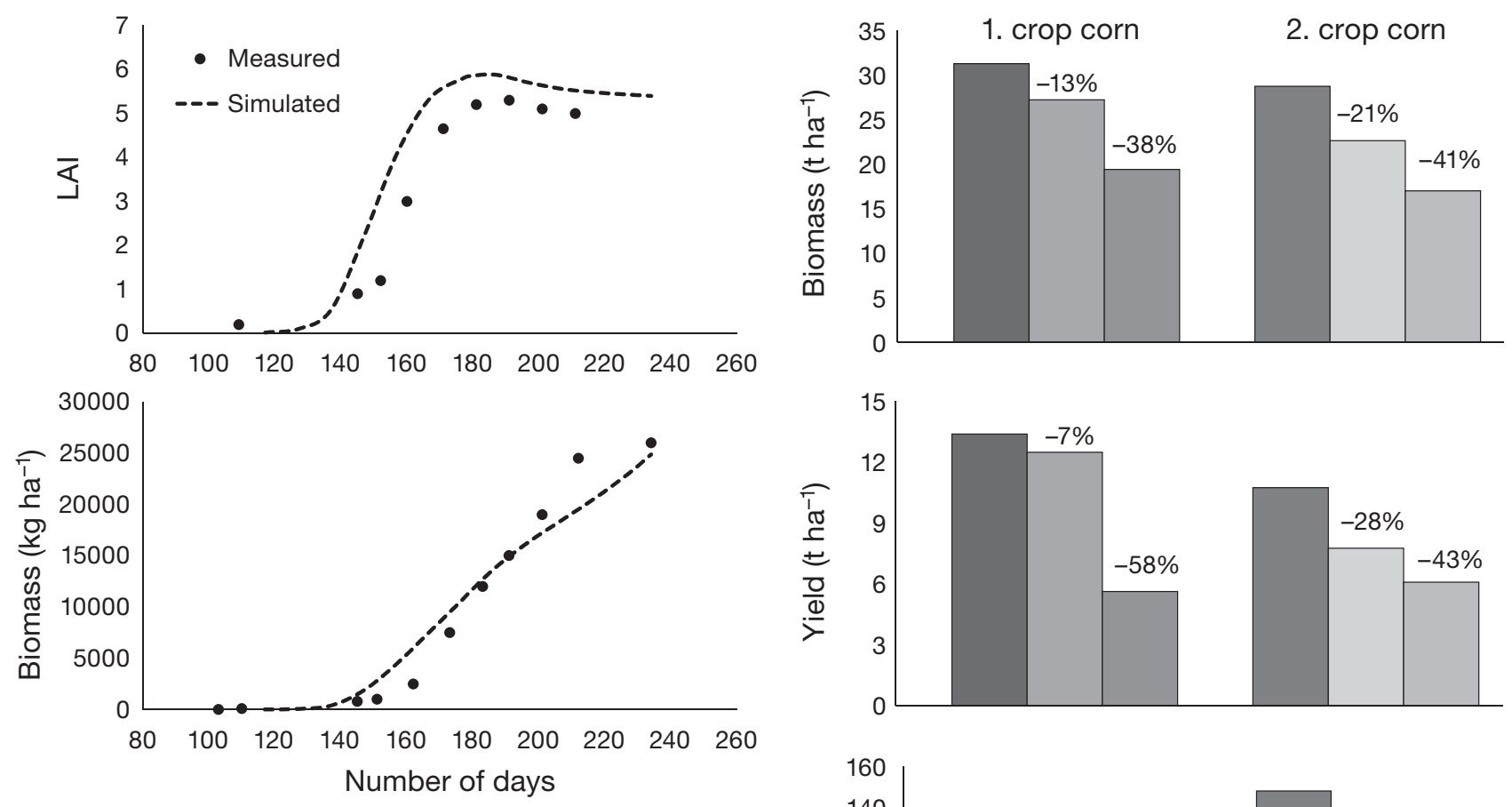

Fig. 12. Measured and simulated leaf area index (LAI) and biomass for first-crop corn in Turkey

Adana experimental station for first-crop corn is presented here to illustrate the agreement between the simulated and observed Leaf Area Index (LAI) and biomass. The slight systematic overestimation of LAI by the WOFOST model was detected only for this location; however, the crop biomass was captured by the model better compared with LAI. For secondcrop corn (data not shown), the model simulated the LAI with an underestimation of about $3 \%$, whereas the simulated biomass was $6 \%$ higher than the observed biomass (Fig. 12). The crop model predicted the grain yields of first- and second-crop corn with only $3-6 \%$ and $4-9 \%$ negative biases, respectively. Calibration and validation experiments generally showed a good fit for LAI and above-ground biomass for corn crops in all 4 locations. Also the time series of observation and simulation (e.g. LAI, biomass) created for the calibration and validation processes were tested statistically, and the average correlation coefficients for the Pearson and Spearman's rank tests were 0.93 and 0.91 , respectively.

Accelerated plant development resulting in hastened maturation for first-crop corn may be expected as a consequence of temperature rise. In the process of simulated climate change, the LAIs decrease by $15 \%$, and growing period is becoming shorter (by about $14 \mathrm{~d}$ ) compared with the RF period under potential conditions (Fig. 13). As a consequence of the

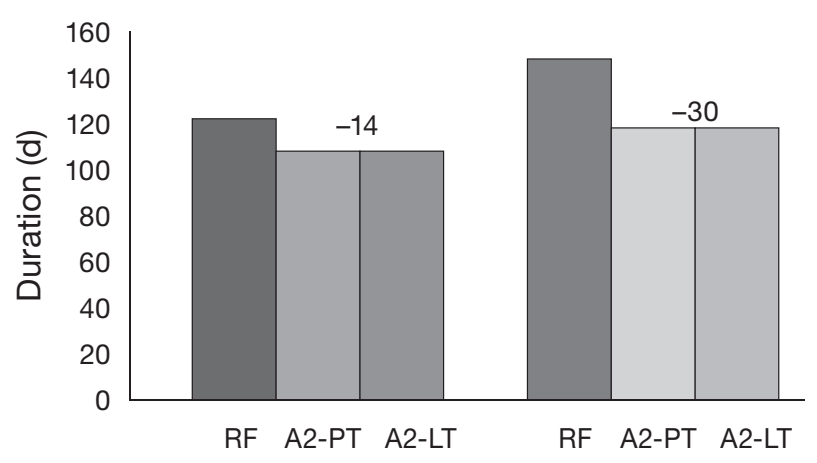

Fig. 13. Projected changes in biomass, yield and growth duration for first- and second-crop corn grown in the Cukurova Region (RF, A2-PT and A2-LT indicate simulation results for reference period, potential level under A2 scenario and water-limited under A2 scenario conditions, respectively). Values above bars: (top and middle) percent declines from $\mathrm{RF}$; (bottom) decline in duration (d) from $\mathrm{R}$

projected climate change trends described above, total biomass and grain yield of first-crop corn are predicted to decrease by about 13 and $7 \%$, respectively.

As evident from the trends in drought characteristics, the future drought events over Turkey will be more frequent. This means a tendency towards an increase in shortage of water resource $(40 \%$ reduction in amount of irrigation water applied under potential production conditions) and therefore less water availability for irrigated agriculture. As we assumed that farmers may react differently to water shortage, we tested some commonly used deficit irrigation applications such as using water-saving irrigation techniques, reducing the amount and increasing the 
interval of water applied and delaying the first irrigation and early irrigation cut-off. The highest yield was obtained from the irrigation scenario - first irrigation, $35 \mathrm{~d}$ after sowing; irrigation interval, $10 \mathrm{~d}$; number of irrigations, 5 ; irrigation cut-off date, end of August under limited-water conditions - and accordingly it has been applied for the future simulations. The same length of growing period would also be expected with reduced irrigation application for the first-crop corn; however, expected reductions for the LAI and yield (Fig. 13) rose by up to 28 and $58 \%$, respectively, under deficit irrigation conditions. Statistical analysis showed that projected reductions in yield are significant, and crop growth in the future will be much more sensitive to changes in both climate and water stress.

Our simulations indicate that second-crop corn may suffer from climate change-induced high temperatures resulting in shortened growing seasons: $30 \mathrm{~d}$ for potential and limited conditions (Fig. 13). Crops will experience reductions in leaf area, aboveground biomass and yield under both growing conditions (Fig. 13). These reductions may exceed $40 \%$ under water-limited conditions, or may only be 20 to $30 \%$ if sufficient water for crop growth is available. Under a deficit irrigation scenario, the coefficients of variations of simulated parameters for the RF period are smaller than those for the A2 period (data not presented), indicating that corn is sensitive to water stress.

\section{DISCUSSION}

In the present study, we analyzed results of RegCM3 projections of changes in temperature and precipitation for Turkey. We assessed the possible changes in droughts under projected climate conditions and the relationship between climate and agricultural productivity by using a crop growth model to determine the effect of projected climate on corn growth and yield in a typical Mediterranean agricultural region in Turkey.

Although daily difference (considering the total annual precipitation) revealed an adequate representation by the model, seasonal precipitation and temperatures were harder to reproduce using the model (Table 5). Krichak et al. (2011) revealed that topography and coastal characteristics of the eastern Mediterranean also influenced the spatial distribution of precipitation patterns in the region, especially in the mountainous and immediate coastal areas, all of which can complicate the use of RCMs in this region. Similar biases for temperature and precipitation over the Mediterranean region including Turkey, obtained from the simulation experiments by using RegCM3 forced by the fvGCM (e.g. Krichak et al. 2007, Önol \& Semazzi 2009) as well as by using different regional climate models with various initial and boundary conditions, have been reported previously (e.g. Demir et al. 2008, Gao \& Giorgi 2008, Giannakopoulos et al. 2010). Reasonably good correlations between drought indices calculated based on the simulated (RegCM3-ERA40) and observed climate parameters were obtained; deviations could be related to the over- and underestimation of the precipitation and maximum temperature for some areas by the RegCM3.

Results of our simulation experiment confirm earlier projections (Gao \& Giorgi 2008, Önol \& Semazzi 2009) on notable climate change signals over Turkey in the late 21st century. Our simulation results confirm findings by Gao \& Giorgi (2008) and Önol \& Semazzi (2009) that the western region of Turkish cities may experience more frequent heat waves in the future. On an annual basis, our RegCM3 experimental results show widespread precipitation decreases (20 to $40 \%$ ) throughout the country except for the north Black Sea coast, which are in line with previous findings from other researchers (Gao et al. 2006, Demir et al. 2008, Gao \& Giorgi 2008, Giorgi \& Lionello 2008, Önol \& Semazzi 2009, Krichak et al. 2011). Projected increases in minimum temperatures during the winter over eastern Anatolia will probably affect snow conditions over the mountains. Similarly, Önol \& Semazzi (2009) inferred that the increase in interseasonal temperature differences, of around $4^{\circ} \mathrm{C}$, could significantly shift the timing of the transition between the seasons.

Global warming is not only associated with a rise in air temperature near the surface, but also enhances drying near the surface. The increased risk of drought duration, severity and extent is a direct consequence (Trenberth et al. 2003), and previous theoretical expectations are now being realized in various parts of the world (Dai et al. 2004, Nicholls 2004) including Turkey (e.g. Türkeş 2003, Sensoy et al. 2008, Topcu et al. 2010, Deniz et al. 2011). According to our drought analysis, particularly severe drought conditions are expected in the western Mediterranean and Aegean regions, although other regions of the country will also face more frequent, intense and long-lasting droughts. This affects most agricultural production areas including central Anatolia (an important wheat production area for Turkey), the Mediterranean (mainly corn and citrus products), 
southeastern Anatolia (cotton and cereals) and the Aegean (fruit trees, cotton, corn) regions. As a consequence of meteorological and hydrological droughts, shortages in water resources and losses in crop yields can be expected. In terms of Erinç's (1965) aridity classification, the major cultivable areas of the country under consideration exhibit a climate regime shift, which also implies a shift in potential vegetation cover by the end of the 21st century. Notably, both wet and drought conditions may occur more often in the Marmara region.

In the Mediterranean countries including Turkey, cereal yields are limited by low water availability, restricted rainfall, high evapotranspiration, heat stress and the short duration of the grain-filling period, which makes irrigation important for crop production (Alexandrov \& Hoogenboom 2000, Olesen \& Bindi 2002). Predicted increases in evapotranspiration and reduction in total rainfall associated with climate change may lead to significant increases in crop evapotranspiration and irrigation in some parts of the Mediterranean region (e.g. Rodríguez Díaz et al. 2007, Topcu et al. 2008). According to our results, corn yields are projected to decrease, and growing seasons are predicted to be shortened due to high temperatures and water stress. In accordance with our results, Brown \& Rosenberg (1999) found that the potential productivity of maize in the USA was negatively influenced by the increasing temperature, and yields decreased by as much as $70 \%$ below the baseline (1961-1990) when global mean temperatures increased by $5^{\circ} \mathrm{C}$. Yano et al. (2007) identified a shortening of the corn-growing season by about $9 \mathrm{~d}$ without a $\mathrm{CO}_{2}$ fertilisation effect. Like climate models, using crop models also brings some uncertainties and limitations. Although WOFOST enables crop growth simulation under limited conditions including water and nutrient deficits, the effects of pests and diseases, salinity and combined effects of all limiting factors that are also influenced by climate change cannot be taken into account.

\section{CONCLUSIONS}

Turkey is a country of particular vulnerability to environmental challenges including climate change. The country is highly dependent on agriculture, since agriculture accounts for $27 \%$ of employment and $9 \%$ of the gross domestic product. Furthermore, around one-third of the country's population lives in rural areas. Agriculture consumes 75 and $30 \%$ of total and renewable water resources, respectively, al- though with low efficiency. While the annual per capita water availability was $1430 \mathrm{~m}^{3}$ in 2008 , based on the 2008 population figure of about 72 million, availability is estimated to decline to $1000 \mathrm{~m}^{3}$ per capita per year by 2030 for an expected population of 100 million, which means the country will experience a 'water scarcity'. Hence, alterations to precipitation and temperature, including the statistical likelihoods of extremes such as drought, are of major importance. Recent analysis has already revealed increasing trends of droughts and related crop failures in many parts of the country. Future vulnerability, however, will depend not only on climate change but also on development plans, so that appropriate strategies followed by sustainable development can reduce vulnerability to climate change. Therefore, analysing past and future climate patterns can shed light on the range of climate possibilities for the country and result in more informed management decision making.

The results presented herein were obtained in a climate change simulation experiment that used the RegCM3 model configured for its application over a relatively small domain covering Turkey and adjacent areas to downscale results of a global climate change simulation experiment for 2 time periods (1961-1990 and 2071-2100). The model was performed in accordance with the A2 greenhouse gases emission scenario, by using a 'state of the science' atmosphere-ocean global climate model fvGCM from NASA. Taking into account the above limitations and associated uncertainties, our results warrant further research, not only on climate change projections that use different climate models and scenarios, but also on effects of climate change on water resources as well as water availability for rain-fed and irrigated agriculture, and as a consequence for agricultural production. Flows of Turkish rivers have decreased significantly during the last decades in already water-stressed regions in Turkey. The Euphrates and Tigris rivers constitute almost onethird of the water potential in the country and discharges from these rivers largely come from snowmelt. Hence, increases in winter temperatures and decreases in precipitation can alter the season for snowmelt, and subsequently the discharge of the rivers and water availability for the countries downstream. Also, other highly vulnerable regions like the Aegean (including Gediz, Büyük Menderes and Küçük Menderes river basins) and Mediterranean (including Seyhan and Ceyhan river basins) are expected to face increased risks of summer water shortages and consequently crop failure in the future. 
While the above-mentioned basins are generally important for crop production under irrigation, rainfed agriculture in the central Anatolia region (the Konya closed basin) is also projected to be significantly affected by the precipitation decreases during the winter and during severe droughts. We used different drought indices as indicators to detect potential effects of climate change; however, a runoffbased drought index like the Standardized Runoff Index (SRI) could provide more relevant indications of drought and also help to assess associated risks for irrigated agriculture.

Acknowledgements. We gratefully acknowledge the scientific and technical support with regard to the RegCM3 from Dr. F. Giorgi and Dr. X. Bi from the Abdus Salam ICTP. We extend our gratitude to Dr. H. Tatli from Canakkale 18 Mart University for providing us the SPI program. We also thank Dr. S. O. Krichak for his valuable comments and suggestions, which significantly helped to improve this paper. Our special thanks are extended to 3 anonymous reviewers and the editor for insightful and constructive comments. This study was partially supported by the Cukurova University Fund for Scientific Research Projects (BAP31).

\section{LITERATURE CITED}

Alexandrov VA, Hoogenboom G (2000) The impact of climate variability and change on crop yield in Bulgaria. Agric For Meteorol 104:315-327

- Arakawa A, Schubert WH (1974) Interaction of a cumulus cloud ensemble with the large-scale environment. I. J Atmos Sci 31:674-701

Boogaard HL, Van Diepen CA, Roter RP, Cabrera JCMA, Van Laar HH (1998) WOFOST 7.1 user's guide for the WOFOST 7.1 crop growth simulation model and WOFOST control center 1.5. Tech Doc 52. DLO-Winand Staring Centre, Wageningen

Brown RA, Rosenberg NJ (1999) Climate change impacts on the potential productivity of corn and winter wheat in their primary United States growing regions. Clim Change 41:73-107

> Coppola E, Giorgi F (2005) Climate change in tropical regions from high-resolution time-slice AGCM experiments. Q J R Meteorol Soc 131:3123-3145

> Dai A, Trenberth KE, Qian T (2004) A global dataset of Palmer drought severity index for 1870-2002: relationship with soil moisture and effects of surface warming. J Hydrometeorol 5:1117-1130

Demir I, Kılıç G, Coskun M (2008) Climate projections over Turkey using the PRECIS. Proc 4th Atmospheric Sci Symp. Istanbul Technical University, Istanbul, p 365-373 (in Turkish)

Deniz A, Toros H, Incecik S (2011) Spatial variations of climate indices in Turkey. Int J Climatol 31:394-403

Dickinson RE, Henderson-Sellers A, Kennedy PJ (1993) Biosphere-atmosphere transfer scheme (BATS) version $1 \mathrm{E}$ as coupled to the NCAR community climate model. NCAR Tech Rep NCAR/TN-3871STR. National Center for Atmospheric Research, Boulder, CO
Easterling W, Aggarwal P, Batima P, Brander K and others (2007) Food, fibre and forest products. In: Parry ML, Canziani OF, Palutikof JP, van der Linden PJ, Hanson CE, (eds) Climate change 2007: impacts, adaptation and vulnerability. Contribution of Working Group II to the Fourth Assessment Report of the Intergovernmental Panel on Climate Change. Cambridge University Press, Cambridge, p 273-313

Erinç S (1965) Climatology and its methods. Istanbul University, Institute of Geography Press, Istanbul (in Turkish)

Gao X, Giorgi F (2008) Increased aridity in the Mediterranean region under greenhouse gas forcing estimated from high resolution simulations with a regional climate model. Global Planet Change 62:195-209

$>$ Gao X, Pal JS, Giorgi F (2006) Projected changes in mean and extreme precipitation over the Mediterranean region from a high resolution double nested RCM simulation. Geophys Res Lett 33:L03706. doi:10.1029/2005GL024954

Giannakopoulos C, Hadjinicolaou P, Kostopoulou E, Varotsos KV, Zerefos C (2010) Precipitation and temperature regime over Cyprus. Adv Geosci 23:17-24

> Giorgi F, Lionello P (2008) Climate change projections for the Mediterranean region. Global Planet Change 63: 90-104

Grell GA (1993) Prognostic evaluation of assumptions used by cumulus parameterizations. Mon Weather Rev 121: 764-787

Guttman NB (1999) Accepting the standardized precipitation index: a calculation algorithm. J Am Water Resour Assoc 35: 311-322

Hayes M (1998) Drought indices. National Drought Mitigation Center, Lincoln, NE

Jones RG, Murphy JM, Hassell D, Taylor R (2001) Ensemble mean changes in a simulation of the European mean climate of 2071-2100 using the new Hadley Centre regional modeling system HadAM3H/HadRM3H. Hadley Centre Report. Hadley Centre for Climate Prediction and Research, Exeter

Kahya E, Kalayci S (2004) Trend analysis of streamflow in Turkey. J Hydrol 289:128-144

Krichak SO, Alpert P, Bassat K, Kunin P (2007) The surface climatology of the eastern Mediterranean region obtained in a three-member ensemble climate change simulation experiment. Adv Geosci 12:67-80. www.adv-geosci.net/ $12 / 67 / 2007$

Krichak SO, Breitgand JS, Samuels R, Alpert P (2011) A double-resolution transient RCM climate change simulation experiment for near-coastal eastern zone of the Eastern Mediterranean region. Theor Appl Climatol 103: 167-195

Kutiel H, Türkeş M (2005) New evidence about the role of the North Sea - Caspian Pattern (NCP) on the temperature and precipitation regimes in continental central Turkey. Geogr Ann Ser A 87:501-513

McKee TB, Doesken NJ, Kleist J (1993) The relationship of drought frequency and duration of time scales. In: Proc 8th Conf Appl Climatol, 17-22 January 1993, Anaheim, CA. Am Meteorol Soc, Boston, MA, p 179-186

McKee TB, Doesken NJ, Kleist J (1995) Drought monitoring with multiple time scales. In: Preprints 9th Conf Appl Climatol, 15-20 January 1995, Dallas, TX. Am Meteorol Soc, Boston, MA, p 233-236

Nakicenovic N, Alcamo J, Davis G, de Vries B and others (2000) IPCC special report on emissions scenarios. Cambridge University Press, Cambridge 
Nicholls N (2004) The changing nature of Australian droughts. Clim Change 63:323-336

> Olesen JE, Bindi M (2002) Consequences of climate change for European agricultural productivity, land use and policy. Eur J Agron 16:239-262

Önol B (2007) Downscaling climate change scenarios using regional climate model over Eastern Mediterranean. Institute of Basic and Applied Sciences, Istanbul Technical University

Önol B, Semazzi FHM (2009) Regionalization of climate change simulations over the Eastern Mediterranean. J Clim 22:1944-1961

Oral N (2008) Agriculture in Turkey in 2007. www.zmo.org. tr/resimler/ekler/20a7ce2a627ba83_ek.pdf?dergi=139 (in Turkish, accessed 14 Feb 2011)

Pal JS, Small EE, Eltahir EAB (2000) Simulation of regionalscale water and energy budgets: representation of subgrid cloud and precipitation processes within RegCM. J Geophys Res 105:29579-29594

Pal JS, Giorgi F, Bi X, Elguindi N and others (2007) Regional climate modeling for the developing world: the ICTP RegCM3 and RegCNET. Bull Am Meteorol Soc 88: 1395-1409

Rodríguez Díaz JA, Weatherhead EK, Knox JW, Camacho E (2007) Climate change impacts on irrigation water requirements in the Guadalquivir River Basin in Spain. Reg Environ Change 7:149-159

Rosenzweig C, Parry ML (1994) Potential impact of climate change on world food supply. Nature 367:133-138

Sen B (2009) Assessing impacts of climate change on 1st and 2nd crop corn yields using regional climate models in the Cukurova District. PhD thesis, Cukurova University, Adana (in Turkish)

Sensoy S, Alan I, Demircan M (2008) Trends in Turkey climate extreme indices from 1971 to 2004. BALWOIS Conf Water Observ Inform, 27-31 May 2008, Ohrid, Macedonia. Balkan Institute for Water and Environment, Montpellier. http://balwois.com/balwois/administration/full_ paper/ffp-1000.pdf

Strzepek K, Yohe G, James Neumann J, Boehlert B (2010) Characterizing changes in drought risk for the United States from climate change. Environ Res Lett 5:044012

Tezcan L, Ekmekci M, Atilla O, Gürkan D and others (2007) Assessment of climate change impacts on water resources of Seyhan River Basin. The Final Report of ICCAP. Impact of Climate Changes on Agricultural Production System in the Arid Areas, Kyoto, p 59-72

Tonkaz T (2008) Trend analysis of reference evapotranspirations in the GAP Region. In: Proc Conf Irrigation and Salinty, 12-13 June 2008, Sanluurfa, Turkey, p 297-302

Topaloglu F (2006) Trend detection of stream flow variables in Turkey. Fresenius Environ Bull 15:644-653

Topcu S (2011) Water for agriculture: a great but inefficient consumer. In: Kibaroğlu A, Klaphake A, Kramer A, Scheumann W (eds) Turkey's water policy, national frameworks and international cooperation. Springer-Verlag, Berlin

Topcu S, Sen B, Giorgi F, Bi X, Kanit EG, Dalkilic T (2008) Impact of climate change on agricultural water use in the Mediterranean Region. In: 13th World Water Congr, 1-4 September 2008, Montpellier, France. International Water Resources Association, Montpellier. www.iwra.org/ congress/2008/resource/authors/abs707_article.pdf

Topcu S, Sen B, Odemis B, Sen B (2010) Vulnerability of water resources under changing climate conditions in Upper Mesopotamia. In: Kirby C (ed) BHS 3rd Int Symp, Role of hydrology in Managing consequences of a changing global environment. Newcastle, UK. British Hydrological Society, London, p 166-175. www.ceg.ncl. ac.uk/bhs2010/BHS\%20Third\%20International\%20Sym posium $\% 202010 \% 20$ Proceedings.pdf

Trenberth KE, Dai A, Rasmussen RM, Parsons DB (2003) The changing character of precipitation. Bull Am Meteorol Soc 84:1205-1217

Trenberth KE, Overpeck JT, Solomon S (2004) Exploring drought and its implications for the future. Eos Trans Am Geophys Union 85:27

Türkeş M (1998) Influence of geopotential heights, cyclone frequency and Southern Oscillation on rainfall variations in Turkey. Int J Climatol 18:649-680

Türkeş M (1999) Vulnerability of Turkey to desertification with respect to precipitation and aridity conditions. Turk J Eng Environ Sci 23:363-380

Türkeş M (2003) Spatial and temporal variations in precipitation and aridity index series of Turkey. In: Bolle HJ (ed) Mediterranean climate - variability and trends. Regional Climate Studies. Springer Verlag, Heidelberg, p 181-213

Türkeş M, Tatli H (2009) Use of the standardized precipitation index (SPI) and modified SPI for shaping the drought probabilities over Turkey. Int J Climatol 29:2270-2282

Türkeş M, Erlat E (2005) Climatological responses of winter precipitation in Turkey to variability of the North Atlantic Oscillation during the period 1930-2001. Theor Appl Climatol 81:45-69

Türkeş M, Sümer UM (2004) Spatial and temporal patterns of trends and variability in diurnal temperature ranges of Turkey. Theor Appl Climatol 77:195-227

Türkeş M, Akgunduz AS, Demirors Z (2009) Drought periods and severity over the Konya sub-region of the central Anatolia region according to the Palmer drought index. Turk J Geog Sci (Coğrafi Bilimler Dergisi) 7:129-144

Wilhite DA (2000) Drought as a natural hazard: concepts and definitions. In: Wilhite DA (ed) Droughts: a global assessment. Routledge, London, p 3-18

Wolf J, Van Diepen CA (1995) Effects of climate change on grain maize potential in the European community. Clim Change 29:299-331

- Yano T, Aydin M, Haraguchi T (2007) Impact of climate change on irrigation demand and crop growth in a Mediterranean environment of Turkey. Sensors 7: 2297-2315

Proofs received from author(s): February 27, 2012 